\title{
E1 cos de la dona maltractada sota l'escrutini mèdic: els casos de València i Lleida en la baixa edat mitjana
}

\section{The body of the abused woman under medical examination: the cases of Valencia and Lleida in the Late Middle Ages}

\author{
CARMel Ferragud \\ carmel.ferragud@maux.org \\ Universitat de València - Institut Universitari López Piñero \\ Guillem Roca \\ guillemroca88@gmail.com \\ Museu de la Noguera
}

Resum: A partir dels rics fons en matèria judicial que es conserven als arxius de les ciutats de València i Lleida, hem desenvolupat una recerca sobre la intervenció dels practicants de la medicina com a guaridors i com a experts cridats en els tribunals per determinar la naturalesa i la gravetat de les lesions causades per diferents formes de violència exercida contra la dona: violació, maltractament domèstic, tortura i agressions comunes. Fem una aproximació a la legislació i la contrastem amb la documentació, particularment els testimonis d'individus cridats als judicis. A més, analitzem el paper de l'expert, com és utilitzat pel jutge, les limitacions de la seua aportació i les controvèrsies que suscita. Això en un marc social on la dona pateix moltes agressions enfront de les quals es veu indefensa, que sovint no es denuncien $i$ on sempre parteix amb desavantatge.

Paraules clau: medicina forense, maltractament a dones, tribunals de justícia, edat mitjana

Abstract: Based on the rich judicial sources preserved in the archives from the cities of Valencia and Lleida, we have undertaken a study about the intervention of medical practitioners as healers and experts in the courts of law to determine the nature and gravity of the injuries caused by different means of violence against women: rape, domestic abuse, torture, common assault. We examine the legislation and we compare it with the documentation, namely the testimonies of people who were brought to trial. Yet, we thoroughly analyse the role of the experts, how the judges used the information received from them, the limits of their contribution and the controversy they used to arouse. These situations took place in a setting where women suffered lots of injuries to which they could not defend, and those were hardly ever reported. In brief, women were discriminated by the law.

Keywords: forensic medicine, violence against women, courts of law, Midlle Ages

\footnotetext{
* El present treball s'emmarca dins el projecte del Ministerio de Ciencia, Innovación y Universidades "Narpan II: Ciencia vernácula en el Occidente mediterráneo medieval y moderno (VerMed)" (PGC2018-095417-B-C64), de la Universitat de Barcelona (Ferragud).
}

DATA PRESENTACIÓ: 05/10/2020 ACCEPTACIÓ: 13/10/2020 • PUBLICACIÓ: 10/12/2020 


\section{Introducció}

Els estudis sobre la situació de la dona en temps medievals, des de nombroses perspectives, han proliferat en els darrers anys. Amb l'ús de molt diverses fonts (jurídiques, literàries, arxivístiques...) se n'ha fet una aproximació àmplia per tal de poder copsar quina fou la realitat de la presència social de la dona, una mirada sempre sotmesa a interpretacions que es poden carregar de judicis guiats per idees preconcebudes. Certament, no es pot partir de la consideració d'igualtat entre homes i dones en temps medievals per bastir aquesta anàlisi; seria del tot absurd. És ben sabut que la filosofia natural clàssica havia concebut la dona com un ésser inferior en vàlua a l'home, i així era transmès també pels savis teòlegs i predicadors. Fra Francesc Eiximenis ho proclamava amb claredat: «Dona és home occasionat, menor per natura que hom mascle» (Eiximenis 1981: 12). La missió concebuda per a ella era acompanyar l'home i perpetuar l'espècie, tot tenint cura dels infants. Això comportava tot un seguit de funcions domèstiques que el menoret gironí també va recollir àmpliament en la seua obra. L'estatus jurídic femení era lògicament diferent al masculí i això tenia les seues implicacions a l'hora de viure en família i en societat.

La dona patí en temps medievals els estralls de la violència masculina, però no només, car les baralles i agressions entre dones també foren freqüents (Arias, 2007). Hem de ser cauts a l'hora de fer una anàlisi del fenomen, ja que es pot caure fàcilment en el tòpic de jutjar la societat medieval com extremadament violenta, que ho fou, però molt poc si es compara amb l'actual. Les dones foren víctimes de pallisses, violacions, estupres, raptes i tota mena de vexacions que se'ns puguen ocórrer. Ara bé, això no vol dir que aquests actes es desenvoluparen amb impunitat. Al contrari, la societat medieval estava unida per llaços d'estima i de solidaritat familiar que s'activaven davant d'una agressió, a vegades pel seu propi compte, d'altres a través de les autoritats que s'escarrassaren a punir els malfactors, això sí, seguint unes normes i procediments estrictes de comprovació dels fets. I entre ells hi havia la utilització de perits experts en medicina com a assessors dels jutges.

En el present treball ens hem centrat en diferents tipus de violència exercida contra les dones, la seua atenció mèdica i el trasllat de les causes denunciades als tribunals. El nostre objectiu ha estat veure quan i de quina manera la medicina intervingué sobre aquests cossos femenins colpejats, vexats i mutilats. Hem volgut incidir especialment en l'aspecte tècnic de l'observació del cos per determinar i valorar l'abast de l'agressió i la culpabilitat de l'agressor.

Aquest procés s'ha d'entendre al voltant de la medicalització que va experimentar la societat tardomedieval de la Corona d'Aragó, comuna a tot l'Occident medieval (McVaugh 1993; Ferragud 2019). Cada vegada fou més habitual sotmetre al judici dels practicants de la medicina molts dels problemes als quals s'enfrontava quotidianament la societat medieval i que avui anomenaríem de salut pública. Per això els metges es feren presents en nombrosos àmbits (hospitals, banys, exèrcits, presons...) i, particularment, pel que ací interessa, en els tribunals de justícia, oferint els seus coneixements experts. 
Els escenaris que hem volgut seleccionar com observatori del tema han estat les ciutats de València i Lleida al segle XIV i inicis del XV. Totes dues ciutats conserven un nombre de fonts de caire criminal —molt superior en el cas lleidatà — que ens permeten fer-ne un estudi adient. El tribunal del veguer de Lleida, amb els seus Llibres de Crims, i els registres del Justícia Criminal de València, són observatoris privilegiats (Montanya 2007; Narbona Vizcaino 1983). Es tracta de dues ciutats amb importants diferències; la primera té menors dimensions i un pes inferior dins Catalunya, comparat amb València que era capital d'un regne. Lleida, en canvi, tenia Estudi General amb facultat de medicina des de 1300, i aquest és un punt que, com es veurà, mereix una consideració especial. Amb tot, la ciutat de València comptava amb una nòmina de metges també amb grau universitari, que exercien una gran influència local, per bé que no devien tenir el nom dels lleidatans. En totes dues ciutats estudiades es pot detectar clarament el recurs a experts en medicina en les corts judicials esmentades, i també d'altres, des de mitjans del segle XIV.

En aquest treball hem volgut centrar-nos en l'anàlisi de quatre tipus d'agressions: la del marit sobre l'esposa, les de caire sexual, la de les dones empresonades i torturades i la violència en el marc de la quotidianitat al carrer. Els actes violents podrien haver estat d'altres, que hi eren, i ben esgarrifosos. Però el mostreig ens sembla suficient per tal que es puga apreciar quina va ser la labor dels practicants de la medicina en l'atenció mèdica a les dones, especialment quan es desenvolupava un judici.

\section{Marits maltractadors}

Que els marits agrediren les seues dones era un fet habitual en temps medievals; era un càstig permés i acceptat socialment. Tot $\mathrm{i}$ les limitacions imposades per les lleis, era ben vist que el marit corregira els defectes de la seua esposa amb la finalitat d'educar-la, si bé no ho havia de fer amb massa severitat (García Herrero 2008). Francesc Eiximenis, per exemple, acceptava la correcció física de les dones de baixa extracció social (pageses o esclaves) que no atengueren els consells maritals, però apel lava a la moderació i a cercar alternatives, tot seguint el Dret canònic (Viera / Piqué 1987: 91 93). Tanmateix, els límits aconsellats podien excedir-se amb la condescendència dels codis legislatius i els jutges que els interpretaven. Molt en particular podia resultar dur aquest maltractament a una adúltera, el pitjor dels crims que podia cometre una dona, ni que fora presumptament; en cas de provar-se, el marit podia actuar amb el fuet per salvar el seu honor. Així es contemplava, com ara, en els Furs valencians (Lázaro Guillamón 2018: 92-94).

Un exemple de la crueltat extrema amb què un marit podia fer mal a una dona que ell sospitava l'havia enganyat, el tenim documentat a Lleida en 1388. ${ }^{1}$ El paraire Bernat de Montroig va denunciar el seu gendre, Bernat Giner, hortolà de les monges menoretes de la capital del Segre, per haver maltractat la seua esposa Dolceta. Segons la dona, Giner estava enfurismat perquè Pericó, el fill de pocs mesos que havia parit l'esposa, no era pèl-roig com ell, i això el feia sospitar que no era fill seu.

1 Arxiu Municipal de Lleida (AML), Llibre de Crims, reg. 790, ff. 101r-120v (4-2-1383). 
Un dimecres de Cendra la va escridassar i apedregar, i, a casa, de nou la va agredir amb una branca d'olivera. Dolceta perdé el sentit, i quan va tornar en si estava despullada i gitada al llit. Llavors el marit la va agafar pels cabells i l'arrossegà tota nua per la casa. Finalment, li introduí la mà en la vagina i li l'esgarrapà. En paraules del sogre: «esgarrapant les parets de dins de la dita natura o con a la dita Dolzeta, diverses e moltes vegades, dient a la Dolzeta: «yo te'n traure la prohityge que hi has!»»». Res pogueren fer des del veïnat per evitar tal càstig, ja que les portes i finestres havien estat ben tancades. L'autoritat, seguint la petició feta per Montroig, va sol licitar Margarida, esposa del carnisser Berenguer Ramon, i a Dolceta, esposa del pagés Joan de Campos, que reconegueren Dolceta. L'informe emès per aquestes dues dones fou clarivident:

\begin{abstract}
havien atrobat e vist que tenie la natura fort inflada a la part de defora, aytant com $\mathrm{I} \cdot$ bona poma ha de gros, per la qual infladura no han pogut veher ni regonèxer quayn mal és de la part de dins la deta natura. E han vist axí meteix e trobat... que ha en les cuixes e en les anques e spatlles e esquena diverses e moltes blavures bé de amplària quiscuna blavura de una mà $\mathrm{e}$ més avant. Les quals blavures par que sien estades feytes ab colps de bastó e de pedra. E axí meteixs han trobat la deta Dolceta tota pelada en los cabeylls del cap.
\end{abstract}

Tal com deia Dolceta i confirmaven els testimonis, l'informe pericial mostrava totes les agressions, en el seu sexe i per tot el cos, incloent-hi l'arrancament de cabells. La inspecció de l'agressió fou encarregada a dones, sens dubte pel fet que hi havia pel mig un examen d'un cos, incloent-hi el sexe, de dona. Un altre assumpte eren les marques dels colps, els blaus, que normalment haurien estat objecte de l'observació d'un barber cirurgià (Ferragud 2016). El justícia confià que els coneixements d'aquestes dones eren suficients per fer una valoració adequada de totes les nafres que havia patit aquella dona.

El 13 de setembre de 1406, a Lleida, un grup il lustre de metges, el cirurgià i professor de l'Estudi General Pere de Lligalbé, i els físics Joan Maguesa, també professor de l'Estudi, i Guillem Berbegal, ${ }^{2}$ van examinar el cadàver de Guillamoneta, esposa del pagès Pasqual de Camp, que havia mort presumptament a conseqüència d'una pallissa propinada pel marit. El cos va ser exhumat i examinat a l'església de Sant Martí. Els metges no van poder arribar a cap conclusió que permetera inculpar el marit, perquè el cos presentava ja un estat de descomposició que dificultava obtenir qualsevol informació. Deia Lligalbé, que «no ha vist que tumefacció alguna fos en lo cors seu, e açò per tant com havia gran spay que era morta ni 'n poria dir en veritat», i per la seua banda Maguesa deia,

2 Pere de Lligalbé fou professor de la facultat de medicina de Lleida en 1406 (Lladonosa Pujol 1974: 422). Està documentat en dos processos de 1399. En el primer cas apareix socorrent a un home malferit després d'una baralla amb coltells al barri de Magdalena (AML, Fons Municipal, Llibres de Crims, reg. 798, f. 59r; 8-5-1399). En el segon cas, datat el 30 de juliol del mateix any, fa una dessospitació (examen pericial sobre el pronòstic d'una ferida) acompanyat del físic Joan de Prusia, també professor de la facultat de medicina lleidatana, i del cirurgià Ramon Ponç (AML, Llibres de Crims, reg. 799, f. 31v). Joan Maguesa era mestre en medicina i sabem que va ser contractat el 1404 per fer la lectura de medicina a l'Estudi General a partir del dia de Sant Lluc en endavant (Arxiu Capitular de Lleida, Llibre de Seguretats, reg. 327, s. d.). De Guillem Berbegal no tenim notícies documentals. 
que «atés que la dona havia gran spay que era morta e de tot freda, que él ni metge del món no porien dir ab veritat que la dita dona tingués colps neguns, majorment com no veés res inflat en lo cors de la dita dona sinó algunes glapes per congelació de la sanch y de mortificació de aquella» (Camps Surroca i Camps Clemente 1998a: 93, 96 i 100). No tenim notícies d'exhumacions de cadàvers en l'àmbit de la Corona d'Aragó per obtenir una informació forense. Per això aquest cas mereix una atenció especial, ja que es procedeix a una intervenció delicada des d'un punt de vista religiós — desenterrar un cadàver - en què hi ha una incriminació d'un personatge que no sembla especialment rellevant i que és acusat d'haver maltractat l'esposa. Les garanties processuals, malgrat que la víctima fou una dona, hi són presents.

Pocs mesos després, el 26 de maig de 1407, el justícia criminal de la ciutat de València, acompanyat pel seu saig, es van desplaçar a casa del paraire Galceran Verdejo, alertats per alguns veïns que l'acusaven d'haver matat a colps la seua dona Blanqueta. ${ }^{3}$ Quan el justícia va arribar al lloc dels fets, es va trobar amb el cadàver. Davant els dubtes sobre el que havia passat, el justícia va demanar que alguns metges es desplaçaren per examinar el cos sense vida de Blanqueta i que determinaren si existien ferides o algun tipus de fractures ocultes, que pogueren ser prou evidents per a denunciar el marit.

Davant les reiterades denúncies dels familiars de la difunta, Galceran va demanar que fora publicat el peritatge que els metges havien realitzat per tal de rentar la seua imatge i proclamar la seua innocència. Els metges triats van ser Lluís Gil i Pere Ballester, ${ }^{4}$ que van constituir una comissió al costat de Francesc Cardona, «lo qual usse de medeçina», que era el metge que havia atès a Blanqueta abans de morir. Era habitual que entre els perits figurara el metge que havia intervingut en la malaltia del difunt, per comptar amb una informació més adequada que permetera fer una aproximació millor a les causes de la mort. Tots tres van ser cridats pel justícia i, després de fer jurament, van oferir les conclusions que es derivaven de la seua actuació pericial com a experts. Els metges van manifestar haver trobat Blanqueta en un llit de la casa, encara sense amortallar, i que no van descobrir cap colp que poguera haver-li causat una lesió. Per contra, van trobar-hi «pulgó negre», que, segons aquests metges, «sol apparer en temps pestilençial». ${ }^{5} \mathrm{~A}$ aquesta dada va afegir

3 Arxiu del Regne de València (ARV), Justícia Criminal, núm. 18, mà 6, ff. 10r-14r.

4 Totes les dades sobre practicants de la medicina que fem servir en aquest treball han estat obtinguts de Fresquet $e t$ al. (2002). Lluís Gil va ser un físic i cirurgià, ciutadà de València, que va actuar d'examinador de metges durant els anys 1429 i 1437. Va ser triat «conseller de parròquies», és a dir, membre del consell municipal, durant l'any 1429. Molt més coneguda és la trajectòria biogràfica del seu fill Pere, també cirurgià i el seu hereu universal. Pere Ballester va ser un batxiller en medicina que va actuar com a examinador de cirurgians en 1430, 1431 i 1433. Va ser triat com «conseller de parròquies» en 1436. No tenim més dades biogràfiques si exceptuem alguna activitat creditícia en què es va veure involucrat.

5 «Pulgó» és una paraula que només hem pogut localitzar en contextos més tardans, d'època moderna, malgrat que hi apareix esmentada en els poemes d'Ausiàs March (CII, 177-180). Fou el mot utilitzat per designar les erupcions cutànies que s'esdevenien amb motiu d'algunes febres i també podia ser un signe de la pesta. Al llarg del XVI començà 
Cardona, que durant aquells dies Blanqueta va patir de febres, un altre dels símptomes que solien tenir els malalts de pesta («que aquella havia febra pestilenciall, e que aquella dita febra l'avia acabada e morta»). Efectivament, com van explicar els tractadistes que es van ocupar del tema, als empestats els solia sobrevenir la «febre pestilencial» $\mathrm{O}$ «febre podrida», que havia extingit la seua calor natural i produït la mort (Alcanyís 2008: 90). En canvi, res es diu dels abscessos o bubons, tan presents en els empestats, com solien mostrar els tractats mèdics: «E com en les febres pestilencials se acostumen de mostrar bubons o vèrtoles» (Alcanyís 2008: 104). Tot plegat fa pensar que en aquest cas no es tractava de cap episodi de pesta, com els que assolaven temporalment la ciutat. Rubio Vela (1994-95: 1193), en un minuciós estudi sobre les epidèmies a la València del Quatre-cents, va detectar dos brots importants a inicis de segle, el de 1403 i el de 1410, i no sembla que entre aquests anys hi haguera cap signe visible del contagi. ${ }^{6} \mathrm{El}$ cas de la difunta cal relacionar-lo amb una malaltia concreta i puntual de caràcter infecciós, que podria correspondre amb el que avui anomenem tifus exantemàtic, sense ànim de fer un diagnòstic retrospectiu. I el fet no fa més que remarcar que rere el nom de pesta i pestilència durant l'edat mitjana es va fer referència a un conjunt de patologies que no es poden relacionar unidireccionalment amb la pesta conceptualitzada en el present gràcies a la microbiologia (Arrizabalaga 2017:174-175). Perquè existís una epidèmia de gran extensió havia d'existir necessàriament contagi. Potser sospitaven els metges que el cas de la dona examinada en podia ser un indici, o més bé aquesta fou una més de les ocasions en què determinar l'etiologia d’una alteració epidèrmica fou objecte de controvèrsia (Pastore 1998: 101).

Com sol ser habitual en molts dels judicis de què tenim notícia, ens falta la resolució del cas. No sabem si els marits, presumptes maltractadors, quedaren absolts o foren castigats. Tampoc sabem exactament el paper que pogué tenir el testimoni dels metges, que al final no era sinó una aportació més entre les nombroses veus que escoltava el jutge, $i$ a les quals podia fer cas omís. Però no podem deixar de quedar-nos amb la sospita que la intenció general, de jutges i perits, sempre seria la d'afavorir l'home. Quan en 1407, a Lleida, Francesc Queralt intervingué per valorar el cos d'una dona que havia mort accidentalment per unes ferides a la cuixa i l'engonal, que li havia fet el marit amb el basalard (una espasa curta), un no pot més que sospitar que l'accident era poc creible (Camps Surroca i Camps Clemente 1998a: 97). En aquest sentit, que dones que apareixen mortes amb la sospita que el marit tinga alguna cosa a veure siguen acusades de consumir vi en quantitats desorbitades, també resulta sospitós. ${ }^{7}$ Que Galceran de Verdejo pogués ser exculpat perquè la dona

a utilitzar-se també en el context català el mot «tabardillo», el seu sinònim castellà. Aquest signe podia resultar com a signe excloent de la pesta bubònica (Cremades / Montoya 2010: 142).

6 Aquest cas és molt semblant a un esdevingut a València 15 anys després, quan fou descobert el cos d'un convers i es va sospitar que havia patit un enverinament. Els quatre metges reunits per analitzar el cadàver afirmaren que durant la malaltia havia patit febre pestilencial, i tercianes. La diferència és que aquell any 1422 sí hi hagué pesta. Ferragud, 2016, pp. 132-135.

7 Entre diversos casos podem citar un esdevingut a Barcelona en 1377. El menescal Jaume de Montserrat serà exculpat, amb l'informe preceptiu dels metges, d'haver assassinat la seua muller. Dona malaltissa, es repetirà en nombroses ocasions que abusava del vi (López Rodríguez 2014: 196-137). 
havia mort de malaltia, no vol dir que no la maltractara, com bé afirmaven els veïns. Però encara més difícil resulta pensar que un membre conspicu de l'artesanat local fora condemnat com a conseqüència del testimoni dels metges. ${ }^{8}$

\section{Dones expertes en violacions}

Les agressions sexuals a dones, des de nenes a púbers, joves i dones adultes, solteres o casades, foren habituals en el món medieval. ${ }^{9}$ Tot i que el nombre de casos poden ser sorprenentment escassos quan es consulten els arxius, aquest fet no fa més que ocultar una realitat habitual silenciada per evitar la vergonya de l'agredida i de la seua família. La dona era la garantia de la pervivència del llinatge, i una taca en la seua honra ho era també en la de la família. Per això era lògic que quedaren sense denunciar moltes violacions, en particular de dones adultes (Córdoba de la Llave 1994: 51-52).

Hem analitzat sis casos d'agressions esdevinguts a la ciutat de Lleida, datats entre els anys $1332 \mathrm{i} 1398$, i només un exemple per al cas valencià, on aquesta documentació és de conservació excepcional. Un dels denominadors comuns en tots els casos és l'edat de les dones que pateixen l'atac; es tracta de fadrines, algunes encara en la més tendra infantesa (entre 5 i 7 anys) o adolescents, cal suposar que verges, sorpreses per un agressor quan estan soles, sense testimonis i indefenses; es tracta d'un individu que sol tenir un contacte molt directe amb la violada i la coneix (com ara un treballador de la casa, o bé algú de la casa on aquesta serveix com a criada), o bé actua per un rampell (algunes són sorpreses per l'agressor en el treball, al camp). ${ }^{10} \mathrm{El}$ segon punt comú és que, per unes coses o altres, com ara l'aparició d'alguna persona que pren part en favor de la dona, el violador no pot consumar completament el que era la seua intenció. I, finalment, cal remarcar el que al capdavall és la major preocupació dels pares i parents en tots els casos: la possible pèrdua de la virginitat. Efectivament, en temps medievals, seguint el llegat dels pares de l'església, n'hi hagué un gran interès per preservar intacta aquella part del cos femení anomenada amb mots diversos (tresor, bàlsam, perla); himen és un terme que s'incorpora molt tardanament en la tradició Occidental. La preservació d'aquella minúscula part anatòmica representava l'estat de castedat ideal per a una dona (Luttrel, 1962; Atkinson 1983). El mateix Francesc Eiximenis considerava la virginitat i la seua fragilitat en el seu Llibre de les dones amb especial esment: «Aquest tresor se porta en vexell qui tost se trenca si no és ben guarda» (Eiximenis 1981: 10, 37, 54-55, 59). Però la virginitat era també una consideració moral i resultava especialment sensible per la importància que tenia abans d'arribar al matrimoni; al capdavall, esdevenia una manera més d'exercir control social sobre la dona. En aquest sentit, i des d'un punt de vista mèdic, també la virginitat era l'estadi ideal de la dona; la castedat era

8 Verdejo es va aveïnar a la ciutat de València el 17 de juliol de 1388 (Navarro Espinach 2018: 64), el que indica que portava vora vint anys exercint a la capital un dels oficis més rellevants.

$9 \mathrm{El}$ tema ha estat explorat arreu d'Europa. Una història àmplia ha estat traçada per a l'àmbit castellà a Rodríguez Ortiz 1997, amb un recull extens de bibliografia.

10 Sobre el perfil de les violades segons mostren en general els estudis, vegeu Córdoba de la Llave 2008:193-194. 
una virtut que calia inspirar en les dones joves. Així ho manifestaven les autoritats mèdiques més llegides, que es constituien en reforçadors de les normes socials (Cadden 1995: 262-263).

En els casos que han pervingut és habitual que es practicara un examen pericial per verificar sobre el cos les empremtes del dany causat. El fet certament era comú a tots els indrets on hi era present l'influx del Dret romà (Riera i Sans 1987: 83; Córdoba de la Llave 1994: 55, 126; Kúmper 2014). Generalment aquest examen es produïa com a conseqüència de la petició que en feia l'autoritat judicial. Tanmateix, per iniciativa dels pares es podia sol licitar l'opinió d'algunes dones immediatament després que s'hagueren produït els fets. Aquest és el cas de la lleidatana Domenga, mare de Francesca, una nena de 7 anys que fou violada per Domingo Joan, un empleat del pare de la nena, un teixidor anomenat Jaume Pedro, en el terrat de la casa on vivia, mentre estenia la roba. Entre plors desconsolats i veient l'estat deplorable de la nena que quasi no podia caminar, la mare cridà fins a tres veïnes, Peratona, Miquelena i una tercera de la qual no és possible llegir el nom, per tal que determinaren si la seua filla havia estat desponcellada. ${ }^{11}$ Lògicament, el jutge escoltà al testimoni d'aquestes dones, de les quals en cap moment es diu que tingueren coneixements mèdics, per bé que afirmaren amb rotunditat que la nena estava «mal apareylada en la natura, però no ere corrompuda». Per què Domenga va voler immediatament comptar amb l'opinió d'aquestes veïnes? Segurament perquè sabia que aconseguir testimonis immediats als fets era indispensable per poder demostrar la violació. Així ho exigien les lleis, i els jutges solien ser bastant reticents a acceptar sense més una agressió sexual a una dona, i més si els fets no eren denunciats immediatament. La justícia recorria també a altres detalls precisos de l'agressió per comprovar el grau de violència, la resistència explícita i ferma emprada per la dona i aclarir quines eren les intencions de l'agressor (Córdoba de la Llave 1994: 53-54, 56-59). En el cas de Francesca, agredida mentre regava en una vinya, l'autoritat judicial volgué saber si Bernat, l'agressor, l'havia volgut besar - cosa que no fou molt possible perquè li tenia tapada la boca amb la mà-, com l'havia llançada a terra -agafant-la pels peus-, «si lo ventre e les cuxes sues se mesclaren ab les del dit Berna๖» i si havia aconseguit despullar-la, o, si més no, traure-li les bragues, cosa que no ocorregué per l'arribada d'un pagès i la reacció de Francesca. ${ }^{12}$ És comú que la dona manifestara explícitament la resistència amb crits i tot tipus de colps que pogués donar al seu agressor. De fet, Francesca el va colpejar amb una aixada a les costelles mentre no parava de cridar socors.

Malgrat que la nena havia perdut sang que li havia tacat la camisa que duia posada, això no havia estat suficient per parlar de la pèrdua de la seua virginitat. I és que les proves físiques per determinar la virginitat al llarg dels temps medievals foren diverses. Per als metges la presència de sang no era suficient. La literatura mèdica i ginecològica va recórrer a tres arguments per determinar-ne la pèrdua: la presència o no de l'himen o de sang i la constricció o relaxació de l'úter. Amb tot, proliferaren molts altres mètodes, summament ambigus o complexos com l'estudi de l'orina, el comportament de la dona en qüestió i algun altre de caire astrològic (Kelly 2000: 28-32).

11 AML, Llibres de Crims, reg. 783, ff. 185v-186r (14-3-1369).

12 AML, Llibres de Crims, reg. 794, f. 43v (6-3-1390).

SCRIPTA, Revista internacional de literatura i cultura medieval i moderna, núm. 16 / desembre 2020 / pp. 320-342 ISSN: 2340-4841 · doi:10.7203/SCRIPTA.16.19233 
Però, com diem, serà el jutge qui sol licite habitualment, i sempre a dones, un testimoni expert per determinar la pèrdua de la virginitat. ${ }^{13}$ En els sis casos analitzats a Lleida hi participen 16 dones que emeten un judici sobre la consideració de si ha existit una violació i si l'agredida ha estat desflorada. ${ }^{14}$ Es tracta sempre d'un examen que té lloc fora de la vista dels homes; una sensibilitat comprensible si atenem a l'edat de les afectades. Es diu clarament en el cas d'Angeleta: «apartaren a $\mathrm{I} \cdot$ part la dita fadrina»; amb posterioritat es fa relació al jutge del que han pogut observar. ${ }^{15} \mathrm{El}$ procediment no és mai descrit explícitament, tot i que és evident que la vista i el tacte («vista e regoneguda») juguen un paper determinant. Aquestes dones al ludeixen a l'òrgan sexual femení amb el mot de «natura» $\mathrm{i}$ en descriuen l'estat: «castrada e malmenada de la natura», «corrupta», «corrompuda», «desponcellada», «cascada».

Un aspecte que crida la nostra atenció és aquest nombre de dones participants com a expertes. Habitualment ha d'haver-n'hi almenys dues en la intervenció pericial. Això és normal en qualsevol informe mèdic per raons òbvies; les opinions no sempre coincideixen i això en ocasions porta a cercar-ne més de dues. Quins foren els criteris per triar aquestes dones? En principi podríem pensar que eren els seus coneixements ginecològics derivats de l'atenció a parts i a malalties pròpies de la dona allò que les feia idònies, però en només dues ocasions es diu que la dona encarregada fora comare o madrina. Cal pensar que totes ho devien ser? Fa l'efecte que algunes sí que ho serien. Potser eren tan conegudes que no calia indicar aquesta característica. Però també podem aventurar que les dones en general tenien uns coneixements suficients per atendre moltes malalties i en particular les seues pròpies. Les dones atenien les necessitats mèdiques dels que habitaven sota el seu sostre, familiars, criats i esclaus. Només una part percebien un salari per oferir aquests serveis, però d'altres, encara que pogueren aportar els seus coneixements guaridors, ho feien des de l'altruisme. És molt possible que algunes d'aquestes foren metgesses, no ho sabem, per bé que el més habitual hagués estat que foren així considerades pels escrivans. Fa més bé l'efecte que es tracta de dones acostumades a compartir coneixements sobre allò que ateny a la seua salut, aspectes que romanien opacs als homes, allunyats, per bé que els metges no estigueren desinteressats, de pràctiques obstètriques i ginecològiques (Cabré 2008: 31-36). El Fuero Real castellà ho va deixar molt clar: les veïnes podien intervenir en el reconeixement del cos de dones, i pensem que així

13 A tot arreu d'Europa foren les dones les encarregades de determinar la pèrdua de la virginitat, per bé que els metges tingueren el seu propi discurs al respecte d'aquest procés, la manera de testar-lo i com tractar-lo mèdicament (Lastique i Lemay 1991: 56, 60). La manipulació del cos de la dona, quan els genitals es troben implicats, estigué en general, en temps medievals i moderns, en mans de dones (Pastore 1998: 124-134).

14 En l'únic cas valencià que hem localitzat, un teixidor anomenat Miquel Salto vol fer justícia a una parenta seua que treballa per a Pere de Mora, hostaler del bordell, que suposadament ha estat «sflorada e sponcellada» i sol licitava que fora «regoneguda si aquella ere tal com devie per dues dones sabents e apertes en semblants feyts». ARV, Justícia Criminal, n. 18, mà 8, f. 4, 13-7-1407.

15 AML, Llibres de Crims, reg. 794, f. 48r (4-07-1390). 
s'ha d'entendre en el nostre cas. ${ }^{16}$ Això explicaria que per a cada situació foren sol licitades dones diferents, a diferència del que ocorria amb els homes, on un grup de metges, físics i cirurgians, de prestigi acaparaven la major part dels exàmens pericials de tota mena.

També queda molt clar que quan més edat i més experiència, major era la confiança dipositada en aquestes dones. En cinc casos les citades a testificar eren viudes, i encara cal pensar que altres tenien una certa edat $\mathrm{i}$ eren mares experimentades. Res com aquesta experiència vital per atendre amb garanties processos biològics de tal risc en temps medievals com els parts i conèixer amb detall el curs de les malalties pròpies de les dones. Amb tot, no sabem de la seua consideració social; en tot cas coneixem l'ocupació d'alguns marits, que ens fan pensar en famílies de l'estrat més popular: pellisser, serrador, pagès.

L'exploració del cos de les nenes va donar de vegades resultats inesperats en detectar malalties i malformacions. Quan de l'examen pericial es deriva una condició mèdica diversa al que es podia esperar a conseqüència d'una agressió, el peritatge passava a mans dels metges. Aquest fou el cas d'Angeleta. Les matrones que l'examinaren determinaren que tenia «malautia de menjadura ... en la natura». Per això foren reclamats els serveis del cirurgià Pere Roger i del barber Miquel d'Aler. Aquests manifestaren «que la dita fadrina ja de temps passat ançà ha haüt scaldadura en la natura, e per rahó d'aquella scaldadura ha-se-li fet malautia que li menjave la natura a part de fora, e ya començave a part de dins». ${ }^{17} \mathrm{El}$ fet evidencia que els metges tenien un coneixement de les malalties pròpies de la dona i que hi intervenien quan era convenient (Ferragud 2005: 10, 12-15). Aquest no era un terreny exclusiu de metgesses, com s'ha pretés molt sovint. ${ }^{18}$ En un altre cas l'acte no es va poder consumar per una malformació en la vagina de la nena. Després d’observar-la, les madrines encarregades determinaren que efectivament s'havia intentat la violació, però no s'havia aconseguit, ja que la fadrina havia «haüda una malaltia en lo angonal, que la peyll de la natura li és tant streta que va a ventura que jamés null hom pugue jaure ni conéxer la dita fadrina». ${ }^{19}$ No s'hi estigueren d'afegir que cap dona podria ser més casta, i que més li valdria fer-se monja, una al lusió clara als valors que li eren atribuits a la dona en allò relatiu a la sexualitat i la reproducció en temps medievals.

16 Fuero Real, L. II, t. VI, Ley VIII: «La mujer vecina o hija de vecino, pueda ser testigo en cosas hechas o dichas en baño, horno, molino, río o fuente, o sobre hilados, tejidos, partos, reconocimientos de mujer, y otros hechos mujeriles; pero no en otras cosas, salvo en las que manda la ley» (Pastor 2005). El subratllat és nostre.

17 AML, Llibres de Crims, reg. 794, f. 48r (4-07-1390).

18 Certament la intervenció de cirurgians i barbers sobre les dones i en concret en casos de malalties específiques existeix, per bé que no és massa freqüent a la documentació. Però és un indicatiu que els homes sí estigueren interessats en les malalties pròpies de les dones i hi intervenien. Reflexions de gran interès sobre la intervenció mèdica sobre el cos de la dona, i les particularitats segons ho fan homes i dones, en Green 2000: 58-68.

19 AML, Llibres de Crims, reg. 798, f. 14v (2-08-1398).

SCRIPTA, Revista internacional de literatura i cultura medieval i moderna, núm. 16 / desembre 2020 / pp. 320-342 ISSN: 2340-4841 · doi:10.7203/SCRIPTA.16.19233 
Carmel Ferragud \& Guillem Roca. El cos de la dona maltractada, sota l'escrutini mèdic: els casos de València i Lleida en la baixa edat mitjana

\section{Dones empresonades i turmentades}

Les presons medievals eren espais llòbrecs, humits, freds i amb poca ventilació. Enmig d'aquestes condicions tan dures no era estrany trobar-hi reus que passaven fred i gana, que emmalaltien i morien (Ferragud 2019: 154-157). L'octubre de 1390, el carceller de la presó de Lleida va trobar mort el presoner Joan Gallego. Mentre les autoritats examinaven el cadàver per saber si havia estat una agressió, els presoners van confirmar-los que «bé havie $\cdot \mathrm{V} \cdot \mathrm{o} \cdot \mathrm{VI} \cdot$ setmanes que ere malalt e que axí, dessequin, dessequin, s'ere mort ${ }^{20}$. Semblantment, Elisenda, empresonada per un robatori el 1312, va demanar a un amic que li portara diners i roba d'abric per poder sobreviure (Camps 1998: 53). De la presó de València, reformada el 1419, es deia que «habundàs en fetors e males odors que donaven causa a malalties e infeccions». ${ }^{21}$

Els presoners havien de pagar la seua estada a la presó, el conegut dret de carcellatge, que cobria el sou del carceller, els aliments, el llit i les flassades. A Lleida, Jaume II va regular l'impost el 1300 perquè alguns presoners quodque in captione propterpenuriam fame peribant. A partir d'aquell moment, el carcellatge va ser de 3 diners diaris, però el 1433 va pujar a 4 pels reus de plets civils i a 6 pels presos amb càrrecs criminals; a València, des de temps de Jaume I, era de 2 diners diaris ${ }^{22}$ i a Barcelona, el 1445, de 6 diners (Roca 2017: 216-218; Vinyoles 1997: 74).

Pel que fa a les condicions de vida a la presó les dones ho passaven més malament que els homes, ja que, a part de la duresa d'haver de dur grillons i de l'espai insalubre, patien vexacions de tota mena (Vinyoles 1997: 67-88; Bazán 2008: 213-214). Per evitar escàndols es procurava una separació per sexes, que no sempre s'aconseguia, i hi havia espais de convivència comuna on els presoners tenien contacte entre ells i amb l'exterior a través de finestres amb barrots (Vinyoles 1997: 72). ${ }^{23}$ El 1342, els jurats de València van ubicar la presó femenina per «squivar peccats que ls presos ab les fembres preses per la oportunitat e avivència que havien...» (Serna 1990: 49). El 1389, Borredana va ser reclosa a la presó de Lleida per incitar un home a barallar-se amb un altre. Era metgessa i coneixia algun tipus de sortilegi per escapar del presidi que va compartir amb alguns homes també reclosos. Per realitzar-lo va demanar l'ajuda d'una coneguda seua, Maria, amb qui va parlar «a les rexes de la casa comuna, que la dita na Borredana estava dins en la sala e ela, confessant, de fora». ${ }^{24}$

20 AML, Llibre de Crims, reg. 794, f. 28r (1-10-1390).

21 Arxiu Municipal de València (AMV), A-27, ff. 100r-v (9-03-1419).

22 Llibre 9, Rúbrica 28, Fur 19 (Colón / Garcia 1999: 93).

23 Hi ha una voluntat generalitzada per separar ambdós sexes. A Lleida, Jaume II va manar la construcció de sales per a homes i dones a través d'un privilegi atorgat el 1300 (AML, Llibre Vert de la ciutat de Leyda, reg. 1370, f. 76; 9-01-1299). Els Furs de València també estipulaven una separació per sexes (Serna 1990: 49). Semblantment, a Milà uns estatuts de 1396 reclamaven la necessitat de construir dues grans presons, una per a homes i una altra per a dones (Gazzini 2017: 59-60).

24 AML, Llibre de Crims, reg. 793, f. 32r (30-07-1389).

SCRIPTA, Revista internacional de literatura i cultura medieval i moderna, núm. 16 / desembre 2020 / pp. 320-342 ISSN: 2340-4841 · doi:10.7203/SCRIPTA.16.19233 
Tot i la voluntat de separació no era estrany que es produïren agressions sexuals a les recluses per part del carceller, els seus ajudants o els altres presos (Vinyoles 1997: 75-77). Per aquest motiu es restringien els moviments de les dones dins el presidi i, fins i tot, es va procurar separar les dones «honestes» de les altres mitjançant presons alternatives com el mateix domicili. Per a les dones entrar a la presó implicava una pèrdua d'honra perquè havien de compartir espai amb homes i eren vulnerables a les agressions (Gazzini 2017: 36-37, Bazán 2008: 213, Vinyoles 1997: 76). Això, i l'existència d'una correcció privada realitzada pel marit o el cap de família, explica el nombre reduit de dones a les presons (García Herrero 2008: 39-71, Sabaté 1994: 277-316). ${ }^{25}$

Enmig d'aquestes condicions no ens ha d'estranyar que a les presons la visita de barbers i cirurgians fora habitual, però sempre sota la supervisió del carceller. El Fuero Ju^go castellà ho justificava dient que així s'evitava que els metges proporcionaren verins als presoners per no patir els suplicis. ${ }^{26} \mathrm{El}$ 1378, a la presó de Ciutadella (Menorca), un metge va visitar l'Arnau Esteve —acusat de prendre part en un assassinat - amb seqüeles físiques de la cadena que portava al coll. El físic Domingo Valls va concloure que el reu era en perill de mort i milloraria «si la dita cadena li era mudada del coyll al peu o cama per 'III · o 'IIII · jorns» (Llompart 1991: 96). Cal dir que les presons dedicades a allotjar personatges notables, com la del castell de Xàtiva, diferien només lleugerament. Les malalties provocades per les males condicions higièniques també hi eren habituals i, semblantment, molts presoners resultaven ferits pels grillons. Aquests, però, rebien amb major facilitat les visites de físics, cirurgians i barbers (Ferragud 2019: 154-157).

A la presó s'executava el turment, en les seues diferents variants. No era una pena pròpiament dita, sinó part del desenvolupament del procés judicial, una ferramenta amb la qual es buscava aconseguir la confessió. Els furs de València ho aclarien perfectament quan sancionaven que el turment servia per «haver e saber la veritat del crim o del malefici». ${ }^{27} \mathrm{Cal}$ tenir present que la justícia medieval era exemplificant $i$, per tant, pública, i dins d'aquests paràmetres no tenia sentit una pena realitzada en privat (Narbona Vizcaino 1986: 336-341). Tant a Lleida com a València el turment més comú era la roda (Camps 1998: 20; Narbona Vizcaino 1986: 341). ${ }^{28}$ Com a conseqüència de la seua aplicació els metges havien d'intervenir per reparar les lesions — per exemple, freqüents luxacions que devia ocasionar la roda- permetent, així, ampliar el temps de tortura i les possibilitats de

25 A Bell-lloc d'Urgell, el 1387, dos homes es van barallar perquè un havia renyada la dona de l'altre: «E hoí ell, testis, que 1 dit en Pere Çurro dix al dit Johan Navarro, forner: «En Johan, yo he castigada ma muyller de ço que us ha dit, prech-vos que d'aquí avant no us prengats ab ella. E sinó ho yo us pelaré la barba o vós la pelarets a mi»» (AML, Llibre de Crims, reg. 792, f. 179r; 1-4-1387).

26 «Ningún físico non debe visitar aquellos que son en la cárcel sin aquellos que los guardan: porque nol demanden quel les dé alguna cosa de beber con que mueran con miedo de la pena» (Serna 1990: 44).

27 Furs: llibre 9, rúbrica 6, fur 1 (Colón / Garcia 1999, vol. 7: 53).

28 La roda consistia en lligar els braços del reu per darrera i elevar-lo mitjançant un artefacte alhora que se li col locava un contrapès als peus (Camps 1998: 20). 
confessió (Ferragud 2018: 43). El professional de la medicina era un element clau per controlar adequadament tot el procés (Harang 2017: 138-139, 209).

La presència de metges abans de l'aplicació del turment es produïa, entre altres motius, quan una presonera estava embarassada. El 1342, a Lleida, Gueralda va ser acusada de diversos robatoris i posada al turment. Abans de pujar-hi va demanar «que no la destroncasen ne la fessen afolar del dit prenys». Per això, dues madrines van ser citades per comprovar el suposat embaràs (Camps 1998: 16-17, 19). Semblantment, el 1351, Barcelona i Marieta van ser jutjades per metzineres. Se les acusava d'haver cosit un pegat d'una substància cerosa («cerut») a la camisa d'en Pere Croat per induir-lo a prendre Marieta com a esposa. ${ }^{29}$ Marieta era d'Osca, havia arribat a la ciutat després de la Pesta Negra i — segons va explicar durant l'interrogatori- estava embarassada d'en Pere Croat, del qual n'era l'amant reconeguda («druda»). ${ }^{30}$ En saber-ho, els paers van demanar a una parella de comares que ho confirmaren:

\begin{abstract}
a na Dolceta, muyller que fo d'en Miquel de Cornudela en altra manera apellada na Cavalera, e a na Johana, muyller que fo d'en Antoni Bonet, <madrines>, que anasen regonéxer la dita Marieta si és prenyns. Les quals tornades, feyt primerament sagrament per eles que bé e leament ne faran relació, digueren que eles han vista la dita Marieta en lo Palau de Cervera e regoneguda, e que per cert no conexen en res que la dita Marieta sia prenynada. ${ }^{31}$
\end{abstract}

L'embaràs suposava un impediment per al desenvolupament del procés, ja que una dona embarassada no podia ser sotmesa a turment. Aquesta consideració, que tenia més a veure amb la supervivència del fetus que amb la salut de la mare, apareix referenciada en diverses regions peninsulars i també de més enllà dels Pirineus (Harang 2017: 175-176). A Castella aquest fet estava regulat a les Siete partidas, on s'especificava que s'evitava la tortura a l'embarassada por razón de la criatura que tiene en el vientre, que non merece mal (López 1555: 88v, Partida 7, 30, 2). A València la trobem referenciada en un procés de 1399 en què Llorença, condemnada a ser fuetejada, va poder posposar la sentència pel seu embaràs; un grup de madrines va determinar, a través d'un examen exhaustiu, que estava embarassada de 6 o 7 setmanes. Tanmateix, un nou informe ho va posar en dubte. Les autoritats, per evitar enganys, van seguir el desenvolupament de l'embaràs a través de les madrines i, en visitar-la de nou, aquestes van canviar d'opinió. Jauma, una de les expertes, «duptava que la dita na Lorença fos prenyada per ço com lo qui ss diu prenyat de aquella no crexia ans que era minvat de la primera vegada ençà que la reconegué». Margalida, àlies na Nadala, «dix que ella duptava que

29 «En Johan de les Avelanes, argenter, (...) Respòs e dix que no y sab res, salun que lo dia que les dites fembres prengueren, él, testis, se'n paxà en casa, e can fo alí dix a la dida que està ab el, testis, la qual estave costa aquelles: «Aquexes tues vehines han preses». E aquella dix: «per què han?» «Per tal — dix él, testis, - car dien que han cosit metzines ho no n sé què en la camisa d'en Pere Croat»» (AML, Llibre de Crims, reg. 776, f. 25r; 15-7-1351).

30 «Concubina», segons el Diccionari Català-València-Balear (DCVB).

31 AML, Llibre de Crims, reg. 776, f. 25r (15-7-1351).

SCRIPTA, Revista internacional de literatura i cultura medieval i moderna, núm. 16 / desembre 2020 / pp. 320-342 ISSN: 2340-4841 · doi:10.7203/SCRIPTA.16.19233 
la dita na Lorença fos prenyada per lo senyal de la mamella de aquella». ${ }^{32}$ El físic valencià Jaume Roig, que va realitzar nombrosos exàmens pericials i guaria presoners i presoneres a València, en coneixia els rudiments amb profunditat i va voler recrear un cas semblant al seu llibre Espill. Una dona sentenciada a morir a la forca es quedava embarassada una vegada darrere l'altra evitant, així, el compliment de la sentència. Finalment: «quatre madrines / la remiraren, / he deposaren / ab sagrament / concordantment / no ser prenyada» (Roig 1990: 170-171). El relat de Jaume Roig, amb el seu rerefons misogin però sobretot legitimador de la professió mèdica i el metge universitari per damunt de qualsevol altre guaridor, continua explicant que les madrines es van equivocar i després de penjar a la presonera es va descobrir que, certament, estava gestant.

Els versos de Jaume Roig exemplifiquen una tendència, progressiva durant la baixa edat mitjana, a criminalitzar la medicina practicada per dones. Existien homes i dones, allunyats de la medicina universitària, que realitzaven pràctiques de caire màgic $i$ creencial amb què guarien malalties de persones (febres, gotornons, ferides, malalties infantils...) i animals, predeien del futur, localitzaven objectes robats o perduts i intervenien en qüestions sentimentals (Castells 2013: 235). Com ho feien Barcelona i Borredana, ambdues metgesses, mencionades més amunt. A la primera les autoritats van preguntar-li «si sap ella confessant de metre mal o bé entre $\mathrm{II} \cdot$ persones» i va respondre «que no e que no és metgessa». ${ }^{33}$ Més endavant, però, va confessar haver aprés l'art al costat d'una sarraina anomenada Ferma. A la segona van descobrir-li un tros de pergamí amb una oració que, segons ella, era per «fer desliurar dona que anàs en part». ${ }^{34} \mathrm{I}$ és que la medicina practicada per dones abraçava un ampli ventall de possibilitats terapèutiques. ${ }^{35}$

No hi havia cap diferència entre la pràctica mèdica realitzada per les llevadores del peritatge i la de les dones empresonades; només la finalitat deshonesta de les segones serveix per incriminar-les (Barcelona va manipular la voluntat d'un home i Borredana volia escapar de la presó). Ambdues, les d'un costat i l'altre, utilitzaven amulets, oracions, embruixos i diverses pràctiques mèdiques i empíriques fonamentades en creences diverses, per assistir un part (Vinyoles 2011: 234-239). L'Església baixmedieval va criminalitzar aquesta màgia convertint les endevines, metgesses i comares en l'objectiu de la Inquisició i, progressivament, relegant-les a una posició secundària sotmesa a la figura del metge masculí (Ortíz 1993: 96-99; Vinyoles 2011: 229-230). La criminalització d'aquestes dones queda reflectida en versos del mateix Jaume Roig: Moltes n'han mortes, / en foc cremades, / sentenciades / ab bons processos / per tals excessos, / en Catalunya (Roig 1990: 145).

32 ARV, Justícia Criminal, núm. 49 (26-6-1399).

33 AML, Llibre de Crims, reg. 776, f. 24r (15-7-1351).

34 AML, Llibre de Crims, reg. 793, f. 92r (30-07-1389).

35 És força significatiu el cas de Gueralda de Codines condemnada el 1304 per guarir malalties usant sortilegis (Vinyoles 2010: 234-236; Castells 2013: 237-238).

SCRIPTA, Revista internacional de literatura i cultura medieval i moderna, núm. 16 / desembre 2020 / pp. 320-342 ISSN: 2340-4841 · doi:10.7203/SCRIPTA.16.19233 
Carmel Ferragud \& Guillem Roca. El cos de la dona maltractada, sota l'escrutini mèdic: els casos de València i Lleida en la baixa edat mitjana

\section{Agressions comunes}

Dins la societat medieval la violència esclatava amb relativa facilitat, i la documentació judicial ens mostra els rampells dels homes i dones d'aquells temps que menen a l'agressió. La gent anava armada pel carrer amb coltells i no era estrany que, arran d'una discussió, algú els acabara traient i s'iniciara una baralla, a vegades amb conseqüències fatals. Les autoritats van limitar l'ús d'aquest tipus d'armes; als costums de Lleida s'estipulava la prohibició de portar coltell i, si algú el desembeinava contra algú altre, havia de pagar 60 sous o perdre la mà (Botet 1997: 119, 140), i a València es limitava la grandària del coltell a «un palm d'alna e de $\mathrm{II} \cdot$ dits». ${ }^{36}$ Els humanistes Lorenzo Valla i Francesco Guicciardini van retratar un poble català violent, molts tenien armes, ja foren espases, coltells, ballestes o llances (Sabaté 2007: 16-17). El 1402, arran de les nombroses baralles que hi havia a Lleida, el mostassaf va demanar al consell municipal que «tothom hagués tenir barres ab ganxos a les portes per partir e aturar los barallants»; ${ }^{37}$ és a dir, una perxa per separar les baralles des d'una distància prudent. En un món de solidaritats col lectives les ofenses no requeien sobre l'individu sinó sobre un grup i això, sovint, desembocava en lluites de bàndols que es prenien la justícia pel seu compte (Enjuanes / Roca 2018: 98).

Les dones també s'encabien dins d'aquest món de solidaritats, a vegades com a agressores, sovint com a víctimes (Pastor 2005: 457-460). Certament, una gran part de les agressions documentades a dones eren agressions sexuals com les que hem tractat més amunt. En aquest apartat, però, ens centrarem en altres agressions físiques perpetrades o rebudes per dones.

Una nit d'octubre del 1308, quan ja havia tocat el seny (campana) del lladre, alguns homes de la conguaita de Lleida van topar-se amb Saurina caminant sola pel carrer. Anava sense llum, que com en moltes ciutats era prohibit després de la campana que anunciava l'arribada de la nit. Els va dir que l'havien assaltat i ferit «pel muscle alt del braç squerre ab coltell ho ab espasa». ${ }^{38}$ Llavors van donar-li llum i la van enviar a casa d'un metge anomenat Segatell. La dona, però, no hi va anar i després altres membres de la conguaita van tornar-la a veure pel carrer. Llavors eren a prop de casa d'un metge anomenat Brondat, però com que aquest no els va voler obrir van acabar entrant a casa del metge Ramon de la Coma. ${ }^{39}$

\footnotetext{
36 Furs: llibre 9, rúbrica 7, fur 2 (Colón / Garcia 1999, vol. 7: 53).

37 AML, Fons Municipal, Llibre de Consells Generals, reg. 404, f. 89v.

38 AML, Llibres de Crims, reg. 771, f. 112r (25-0-1308).
}

39 D’aquests professionals mèdics no en coneixem gairebé res. Només en Segatell apareix en un altre document del maig del 1308 atenent a un ferit, que hi va acudir després de rebre els primers auxilis per banda dels veïns (AML, Llibres de Crims, reg. 771, f. 7r; 4-5-1308). El document no introdueix cap detall que ens aporte informació sobre la seua formació, només el cataloga com a «metge», un terme genèric utilitzat per definir tant a homes com a dones dedicats a la medicina. S’intueix, per tant, que no posseïa formació universitària sinó que havia aprés a través d’un sistema artesanal (Ferragud 2012: 120-121). 
Els primers auxilis realitzats per veïns, sovint dones, també apareixen en nombroses ocasions. Per exemple, el 1383 Martina va rebre una pedrada mentre espiava al seu veí a través d'un forat que hi havia a la paret. Sembla que el veí s'entenia amb una dona casada del barri amb qui Martina s'havia barallat de paraula en diverses ocasions. Quan va rebre el cop «ella mes-se cridant son marit, qui ja jahie, e ab algunes de les vehines qui despertaren stubaren ${ }^{40}$ a ella, confessant». ${ }^{41}$ Semblantment, el 1387, Pasquala va ser assaltada pel llaurador Ramon Blasco, que es dirigí cap a ella i «posà-li la mà als pits» abans que pogués recular. ${ }^{42}$ L'home va intentar guanyar-se-la indicant-li que tenia alguna malaltia als ulls i oferint-li oli de Santa Ana ${ }^{43}$ però Pasquala no es va deixar entabanar i el va fer marxar a colps de cistella. Llavors ell «gità en terra a la dita Pasquala e dona-li ·II · o 'III · punyades». Quan Pasquala es va poder aixecar li va intentar llençar una pedra i Ramon «afayats la mà a $\mathrm{I} \cdot$ punyal que portave, lo qual tenie a la part detràs, e trasch lo dit punyal e donan $\mathrm{I} \cdot$ colp per lo ventre a la dita Pasquala». La ferida va ser trasllada ràpidament $\mathrm{a}$ casa pels mateixos veïns - homes i dones - que, veient la gravetat, van decidir cridar al cirurgià Pere Roger. ${ }^{44}$

La medicina escolàstica es va incorporar, de la mà de la figura del dessospitador, dins dels tribunals de justícia de la corona des de finals del segle XIII (Gallent 2000: 16-17). Per això, davant d'una agressió, les diverses corts judicials acudien als experts per avaluar la salut d'un ferit, el seu pronòstic i el cost de medecines i atencions que hauria de rebre per recuperar-se. En els ferits la seua intervenció és clara, però quan es localitzava un cadàver a vegades l'observació del cos la feien els mateixos saigs o les autoritats. A València es va localitzar el cadàver de Margarida, l'esclava tàrtara de Guillem Crespí, que havia caigut del terrat. ${ }^{45}$ Els testimonis van explicar que no havia estat agredida sinó que patia «mal de caure», és a dir epilèpsia, morbus caducus o mal caduc, i que per això s'havia precipitat des del terrat. La dificultat per diagnosticar aquesta malaltia i la

40 «Estubar» apareix sovint en la documentació lleidatana, una de les accepcions que dóna el DCVB és un equiparable a «fomentan», és a dir: «aplicació de medicaments a la part externa del cos, per a fins resolutius o analgèsics»._

41 AML, Llibres de Crims, reg. 790_02, ff. 19r-v (22-5-1383).

42 AML, Llibres de Crims, reg. 792, f. 189r (2-3-1387).

43 Un altre testimoni menciona que es tractava d'oli de Santa Àgata.

44 Durant la segona meitat del segle XIV, apareixen dos metges anomenats Pere Roger a Lleida, possiblement familiars. El 1386, arran d'una baralla entre dos homes al bordell, les autoritats van demanar la dessospitació de les ferides d'en Pere de Perpinyà a «maestre Pere Roger, cirurgià, e en Pere Roger, cirúrgich e studiant en medicina» (AML, Llibres de Crims, reg. 792, f. 88r; 28-8-1386). Quatre anys més tard, havent acabat el seus estudis, el segon metge apareix en un altre procés com a «cirúrgich, batxeller en arts e en medicina» (AML, Llibres de Crims, reg. 794, f. 15r; 13-6-1390). Es tractava, per tant, d'un professional que, com altres, havia assolit una formació universitària àmplia i era considerat tant físic com cirurgià. Això li devia permetre augmentar la seua clientela i l’àmbit d'actuació (Ferragud 2011: 85). Passa un fet semblant amb dos cirurgians lleidatans de finals del segle XV anomenats Joan Pastor, pare i fill, que intervenen en dos peritatges el 1499 (Camps Surroca i Camps Clemente 1998a: 93-94).

45 ARV, Justícia Criminal, vol. 18, mà 11, f. 38 r (18-11-1407).

SCRIPTA, Revista internacional de literatura i cultura medieval i moderna, núm. 16 / desembre 2020 / pp. $320-342$ ISSN: 2340-4841 · doi:10.7203/SCRIPTA.16.19233 
seua aparatositat feien que s'associés amb la possessió demoníaca o amb una corrupció de caire alhora físic i moral; per això els diferents remeis implicaven oracions i medicaments (Viera / Piqué / Camaño 2010: 193-196). En aquest cas, les autoritats no van cridar cap metge sinó que feren «veure e regonéxer la dita dona» per assegurar-se que no havia patit cap agressió.

La presència de metges també es podia produir a instància de l'agressor o d'un familiar per sortir de la presó o reduir la pena (Ferragud 2011: 69-94). A Lleida, el 1352, les famílies de Bernat Durant i Esteve Salvador van barallar-se per una discussió que havia començant entres les esposes. Hi havia ressentiment perquè la filla de Bernat Durant, casat en segones núpcies amb Marió, havia marxat de casa i vivia amb Esteve Salvador «no per amiga, mas que la mantenie». ${ }^{46}$ $\mathrm{Al}$ vespre la discussió va sortir de mare i els homes van acabar protagonitzant una baralla de la qual en van sortir ferits Marió i Esteve Salvador. A instància del darrer, Marió va ser dessospitada pel físic Pere des Prats i els cirurgians Joan Solsona i Guillem Sentís. Els metges van trobar-la ferida al cap i al braç, però van determinar que no era en perill de mort ni pèrdua de cap membre «Déus guardant aquella Marió d'altre accident». Tots tres metges eren força coneguts a la Lleida de la segona meitat del segle XIV. ${ }^{47}$

El metge no sempre era un testimoni imparcial i la seua actuació i declaració podien posar-se en entredit, ja fora per part de les autoritats o pels mateixos implicats. El 1396, a València, el procurador de Mafomadell va posar en dubte el pronòstic que dos metges havien fet de la seua víctima (Ferragud 2011: 80-84).

El darrer cas que mencionarem va tenir lloc a Lleida el 1385. El dissabte 18 de febrer, Francesca pastava al forn d'en Fontova i allí va intercanviar insults amb el forner $\mathrm{i}$ altres dones que hi havia. Els va dir «que totes havien les faldes baxades, que totes eren iguals» $\mathrm{i}$ les altres van cridar-li «bagassa!». ${ }^{48}$ Una testimoni ens presenta Francesca com una dona que «ha mala llengua e desonre tothom». Potser per això s'havia covat un ressentiment que va esclatar aquella mateixa nit quan un desconegut, emparat per la foscor, va llençar-li una pedrada a les costelles i un cop d'espasa al cap. Mentre fugia l'home va proferir insults $i$ amb la veu els veïns van reconéixer que es tractava del notari Andreu Cardós. Després de l'agressió la va tractar un metge determinant que la pedra li havia trencat dues costelles, possiblement es tractava del barber Arnau Ferrer o del cirurgià Ramon Ponç, encarregats del seu tractament durant la convalescència.

46 AML, Llibres de Crims, reg. 777, f. 134r (23-11-1352).

47 Pere des Prats apareix en diversos peritatges entre 1339 i 1384 majoritàriament com a cirurgià, però al final de la seua actuació també se l'anomena físic (1378) i metge (1384). De fet, el 1378 es va negar a atendre una dona que havia caigut per les escales raonant que allò era feina d'un cirurgià (AML, Llibres de Crims, reg. 779, f. 86v; 4-2-1378). Una vida professional tan llarga i aquesta referència indiquen que, segurament, es tracta de dos metges diferents, possiblement de la mateixa família. Els cirurgians Joan Solsona i Guillem Sentís també apareixen documentat realitzant nombrosos peritatge entre 1332 i 1353 i 1340 i 1353 , respectivament.

48 AML, Llibre de Crims, reg. 791, f. 104r (18-2-1385).

SCRIPTA, Revista internacional de literatura i cultura medieval i moderna, núm. 16 / desembre 2020 / pp. 320-342 ISSN: 2340-4841 · doi:10.7203/SCRIPTA.16.19233 
Dotze dies després de l'assalt, i per tal que Andreu poguera sortir de la presó, el seu germà va sol licitar la dessospitació de Francesca per part del conegudíssim físic Nadal Llambrí, professor en la facultat de medicina ${ }^{49}$ i dels cirurgians Pere Roger i Ramon Ponç. Era habitual que un dels metges que tractava el malalt participara del peritatge com veiem en els Furs valencians de 1329 i en un dictamen del consell valencià de 1378 (Gallent 2000: 17-19). Els metges van determinar que «segons cors medicina la dita dona no tem per ocasió de les dites nafres e ferides mort, ne afolament, ne debilitació, sol que la dona sie ben tenguda a prop de metges < ço és dels dits mestres Ramon Ponç e n’Arnau Ferrer, qui la han tenguda tota vegada en cura $>»$. No obstant això, abans que acabara el mes la dona va morir mentre la cuidava una veïna.

Els metges que apareixen en aquest procés també eren força coneguts. Ja hem parlat de Pere Roger; Ramon Ponç apareix realitzant peritatges i cures a la ciutat entre 1378 i 1399 i sabem que ambdós van participar en una autòpsia el 1385 juntament amb Nadal Llambrí i altres membres de l'Estudi General (Camps Surroca i Camps Clemente 1998a: 97-98). Aquest fet evidencia la procedència d'aquests dos cirurgians, també formats en l'àmbit universitari com era habitual en un moment en que la medicina escolàstica s'estava consolidant com una de les peces claus dins els tribunals de justícia (Ferragud 2016: 121-125).

Tot i la gran presència d'homes entre els guaridors mencionats en aquest apartat, cal no perdre de vista que les cures domèstiques, ja foren en el moment de l'accident o durant la convalescència, tenien un importat component femení. Un ferit o malalt greu requeria unes atencions constants, sota el guiatge d'un metge professional o no, que s'allargaven notablement i eren realitzades per dones (Cabré 2000: 21-27; Ferragud 2007: 138-140). Els testimonis d'aquestes dones apareixen de gairell en els documents; són les veïnes que fan els primers auxilis als ferits i també dones com Marió, que va tenir cura de Francesca seguint allò que el barber Arnau Ferrer i el cirurgià Ramon Ponç li manaven.

\section{Conclusions}

Les situacions i espais en les quals el cos de la dona podia patir els estralls de la violència, exercida per homes però també per dones, foren molt diversos. Esdevinguda l'agressió, es produïa una intervenció ràpida per buscar el guariment. Aquesta era una tasca que no necessàriament era encomanada a professionals, sinó a la gent més pròxima. Sovint implicava els veïns i, en particular

49 Nadal Llambrí va nàixer a Morella i va estudiar a Montpeller; durant el darrer quart del segle XIV va establir-se a Lleida on el tenim documentat en diversos peritatge entre 1382 i 1394 . Va ser metge de personatges de l'elit, i així el 1391 va tractar a Joan I quan s'estava a Aitona i patia d'«allargament de ventre» i al comte de Prades en diverses ocasions. També va escriure un tractat de farmacologia avui perdut (Camps Surroca i Camps Clemente 1998b: 112-113; Garcia-Ballester 1987-1988: 130). 
a dones, que podien realitzar els primers auxilis i, també, encarregar-se de les cures i el tractament posterior. De vegades, però, s'acudia immediatament a un barber, autèntic paraigües assistencial de la societat medieval, dels quals l'espai urbà n'estava ple, o, fins i tot, a algun hospital (Ferragud 2015). El ventall de guaridors als que hom podia acudir era divers, pel que fa al tipus i la formació. Ens trobem en un moment en què la medicina escolàstica s'estava imposant com a model, però, tot i això, es mantenien individus, homes i dones, que realitzaven pràctiques empíriques, màgiques i creencials perfectament reconegudes, també per les mateixes autoritats.

Després de l'agressió arribaven les denúncies i els clams davant la justícia. Les inquisicions preliminars i els judicis exigien proves fermes i contundents que verificaren els fets esdevinguts i certificaren la gravetat de les lesions que aquelles dones havien patit. Arribats a aquest punt, els jutges lleidatans i valencians recorrien a una gran diversitat d'experts, de consideració i formació molt diversa. Podia ser un cèlebre físic universitari, professor i membre honorable de la comunitat, un barber o un cirurgià, o fins i tot una comare o una dona del veïnat sense formació llibresca. Després d'observar el cos de la dona afectada tots ells podien aportar dades precises que partien del diferent bagatge formatiu de què disposaven. Per a uns era un coneixement erudit i llibresc; per a altres, producte de la llarga experiència i del coneixement transmés per mestres $i$, en el cas de les dones, adquirit a través d'una espessa i extensa xarxa de sororitat (Ferragud en premsa; Blumenthal 2014). Totes aquestes aportacions tingueren la mateixa validesa perquè, al capdavall, era el jutge qui decidia. És important no deixar-nos enlluernar pels grans noms, pels il lustres doctors universitaris de l'Estudi lleidatà, o els valencians que s'hi havien format. De fet, la fiabilitat del perit també podia posar-se en entredit en moltes ocasions; els testimonis interessats també existien i els jutges ho sabien.

Les dones tenien un estatut jurídic i una consideració diferent dels homes, però pel que feia a la violència que s'exercia contra elles, les lleis i la medicina garantiren la seua cura i salvaguarda, no ho oblidem tampoc, perquè elles eren també la salvaguarda de l'honor dels llinatges i de l'ordre social. La dona vivia immiscida dins del món urbà, era un actor més de les solidaritats veïnals, ofenent-se, instigant i també patint els problemes derivats d'aquestes xarxes de familiars i amics que inclö̈en tots els habitants. La situació més terrible arribava quan la dona es quedava apartada d'aquests vincles, vídua o òrfena, i sense possibilitat d'acudir a la xarxa de solidats veïnal. Protegir la dona era, alhora, protegir els interessos familiars i, quan aquests es veien amenaçats per una agressió, les autoritats havien de respondre ràpidament, si no, s’arriscaven que algú es prengués la justícia pel seu compte allargant el conflicte irremeiablement. Per determinar el o els infractors, la gravetat de l'agressió i el tipus de pena els professionals de la medicina, amb tota la seua diversitat, van esdevenir una eina indispensable dels tribunals de justícia. 
Carmel Ferragud \& Guillem Roca. El cos de la dona maltractada, sota l'escrutini mèdic: els casos de València i Lleida en la baixa edat mitjana

\section{Bibliografia}

Alcanyís, L. (2008) Regiment preservatiu e curatiu de la pestilència, ed. Jon Arrizabalaga, Barcelona, Barcino.

Alcover, A. M. / Moll, F. de B. (2018), Diccionari català-valencià-balear, Institut d'Estudis Catalans Institut Francesc de Borja Moll.

Arias, M. T. (2007), Violencias y mujeres en la Edad Media Castellana, Madrid, Castellum.

Arrizabalaga, J. (2004) «Les Universitats», dins Vernet J. / Parés R. (eds.), La Ciència en la bistòria dels Països Catalans, vol. 1, Dels àrabs al Renaixement, València, Institut d'Estudis Catalans, pp. 371-402.

—. (2017), «La identidad de la Peste en la Europa del Antigo Régimen», dins Sabaté F. (ed.), L'assistència a l'edat mitjana, Lleida, Pafès Editors, pp. 169-181.

Bazán, I. (2008) «La violencia legal del sistema penal medieval ejercida contra las mujeres», Clioes Crimen. Revista del Centro de Historia del Crimen de Durango, 5, pp. 213-214.

Blümenthal, D. (2014) «Domestic medicine: slaves, servants and female medical expertise in late medieval Valencia», Renaissance Studies, 28/4, pp. 515-532.

Botet, B. (1997) Els costums de Lleida, ed. Joan Busqueta, Lleida, Ajuntament de Lleida.

Cabré, M. (2000) «Nacer en relación», dins Cabré, M. / Caballero, C. / Bertran M. / Vargas, A. / Rivera M., De dos en dos. Las prácticas de creación y recreación de la vida y la convivència bumana, Madrid, Horas y horas, pp. 15-32.

— . (2008) «Women or Healers? Household Practices and the Categories of Health Care in Late Medieval Iberia», Bulletin of the History of Medicine, 82/1, pp.18-51.

Cadden, J. (1995) Meanings of sex difference in the Middle Ages. Medicine, science, and culture, Cambridge, Cambridge University Press.

Camps, M. (1993) «Notes sobre els orígens de la prova pericial mèdica a Catalunya», Revista de la Reial Acadèmica de Medicina de Catalunya, 8/2, pp. 89-101.

—. (1998) El turment a Lleida (segles XIV-XVII), Lleida/Alcarràs, Universitat de Lleida/ Ajuntament d'Alcarràs.

Camps Surroca, M., Camps Clemente, M. (1998a) «L'activitat forense dels antics mestre de la Facultat de Medicina de Lleida», Gimbernat, 30, pp. 91-101.

_ (1998b) «Nadal Lembri, mestre en Arts i Medicina, professor de l'Estudi General de Lleida», Gimbernats 30, pp. 111-117.

Castells, P (2013) «"E cert té molt gran fama de bruixa e se fa metgessa e da medecines.' La demonización de las prácticas mágico-medicinales femeninas (siglos XIV-XVI)», Studia historica. Historia medieval, 31, pp. 233-244.

Colón, G. / Garcia, A. (eds.) (1999) Furs de València, vols. 7 i 8, Barcelona, Barcino. 
Carmel Ferragud \& Guillem Roca. El cos de la dona maltractada, sota l'escrutini mèdic: els casos de València i Lleida en la baixa edat mitjana

Córdoba de la Llave, R. (1994) El instinto diabólico. Agresiones sexuales en la Castilla medieval, Córdoba, Universidad de Córdoba.

- (2008) «Consideraciones en torno al delito de agresión sexual en la Edad Media», Clío \& Crimen: Revista del Centro de Historia del Crimen de Durango, 5, pp. 194-202.

Enjuanes, I, Roca, G. (2018) «L'assasinat de Francesca de Fillac a mans del seu marit: anàlisi d'un procés criminal del segle XIV», Shikar, 5, pp. 91-99.

Eximenis, F. (1981) Lo libre de les dones, ed. Franck Naccarato, Barcelona, Universitat de Barcelona/ Curial, 1981.

Ferragud, C. (2005) «Organització social i atenció mèdica a la Cocentaina baixmedieval: el procés a Abrahim Abengalell (1318)», Asclepio, 57/2, pp. 3-24.

- (2007) «La atención médica doméstica practicada por mujeres en la Valencia bajomedieval», Dynamis. Acta Hispanica ad Medicinae Scientiarumque Historiam Illustrandam, 27, pp. 133-135.

- - (2011) «El metge sota sospita. Actuació mèdica en els testimonis pericials a ferits davant la cort del justícia criminal de la ciutat de València (1396)», Recerques: Història, economia i cultura, 62, pp. 69-94.

(2016) «Los peritajes médicos en la Valencia bajomedieval: los casos de envenenamiento», Dynamis, Acta Hispanica ad Medicinae Scientiarumque Historiam Illustrandam, 36/1, pp. 119-141.

. (2015) «Barbers in the process of medicalization in the Crown of Aragon during the Late Middle Ages», dins Sabaté, F. (ed.), Medieval Urban Identity. Health, Economy and Regulation, Cambridge, Cambridge Scholars Publishing, pp. 143-165.

-.. (2016) «El coneixement expert dels cirurgians en els tribunals de justícia valencians: la pràctica de la dessospitació», dins Feller, L. / Rodríguez, A. (eds.), Expertise et valeur des choses an Moyen Agge, II: savoirs, écritures, pratiques, Madrid, Casa de Velázquez, pp. 315-329.

- (2018), «Los espacios de la práctica médica en la Valencia bajomedieval», dins Villanueva Morte, C. / Conejo da Pena, A. / Villagrasa-Elías, R. (eds.), Redes hospitalarias: historia, economía y sociología de la sanidad, Saragossa, Institución Fernando el Católico, pp. 31-52.

—. (2019) Una ciutat medieval en cerca de la salut (Xàtiva, 1250-1500), Catarroja / Barcelona, Afers.

- . (en premsa) «Pensar e custuhir malalts e infants se pertany mils a dones que ha hòmens»: el paper de la dona en l'assistència mèdica domèstica en la Corona d'Aragó baixmedieval, dins Benavent, J. (ed.): El cuidado del cuerpo de las mujeres. Desde la Antigüedad hasta el Renacimiento, València, Tirant lo Blanch.

Fresquet, J. L., Luz López, M., Catalá, J., Micó, J. (2002) Archivo Rodrigo Pertegás. Siglos XI-XV, Valencia, Universitat de València-Fundación Marcelino Botín, CD-rom.

Gallent, M. (2000) «Precedentes medievales de la medicina legal: la 'dessospitació' en el Reino de Valencia», Saitabi, 50, pp. 11-28. 
Carmel Ferragud \& Guillem Roca. El cos de la dona maltractada, sota l'escrutini mèdic: els casos de València i Lleida en la baixa edat mitjana

Garcia-Ballester, L. (1987-1988) «Panorama de la medicina en una sociedad medieval mediterrránea: la Valencia cristiana bajomedieval», Dynamis. Acta Hispanica ad Medicinae Scientiarumque Historiam Illustrandam, 7-8, pp. 59-115.

García Herrero, C (2008) «La marital corrección: un tipo de violencia aceptado en la Bada Edad Media», Clioe Crimen. Revista del Centro de Historia del Crimen de Durango, 5, pp. 39-71.

Gazzini, M. (2017) Storie de vita e di malavita. Criminali, poveri e altri miserabili nelle carceri di Milano alla fine del medioevo, Florència, Firenze University Press.

Green, M. (2000) «Women's Medical Practice and Health Care in Medieval Europe», Women's Healthcare in the Medieval West. Texts and Contexts, Aldershot, Ashgate/Variorum, pp. 39-78.

Harang, F. (2017), La torture au Moyen Âge : Parlement de Paris, XIV-XVe siècles, París, Presses Universitaires de France.

Kelly, K. C. (2000) Performing virginity and testing chastitiy in the Middle Ages, Londres, Routledge.

Kümper, H. (2014), «Learned Men and Skillful Matrons: Medical Expertise and the Forensics of Rape in the Middle Ages», dins Turner, W. J. / Butler, S. M. (eds.), Medicine and the Law in the Middle Ages, Leiden, Brill, pp. 88-108.

Lastique, E., Lemay H. R. (1991) «A medieval physician’s guide to virginity», dins Salisbury, J. (ed.), Sex in the Middle Ages. A Book of Essays, Nova York / Londres, Garland, pp. 56-82.

Lázaro, C. (2018) La condición jurídica de la mujer en los Furs de Valencia, València, Universitat de València.

Llompart, G. (1991) «El curso de la vida en Ciudadela. Una noche de 1378», Estudis Baleàrics, 40, pp. 69-97.

López, G. (1555), Las siete partidas glosadas por el licenciado Gregorio López, Salamanca, por Andrea de Pornonariis.

McVaugh, M R. (1993) Medicine before the Plague: Practitioners and their Patients in the Crown of Aragon (1285-1345), Cambridge, Cambridge University Press.

Madero, M. (1999) «Savoirs féminins et construction de la vérité : les femmes dans la preuve testimoniale en Castille au XIIIe siècle», Crime, Histoire \& Sociétés, 3/2, pp. 5-21.

Montanya, M. (2007), El tribunal de Coltellades: alguns aspectes processals, Lleida, Ajuntament de Lleida.

Navarro, G. (2018) «La organización del trabajo en la Valencia medieval», dins Solórzano, J. A. / Sousa A, (eds.), Trabajar en la ciudad medieval europea, Logroño, Instituto de Estudios Riojanos, pp. 39-72.

Narbona Vizcaíno, R. (1983) «El justicia criminal: una corte medieval valenciana, un procedimiento judicial», Estudis Castellonencs, 3, pp. 287-310.

Ortiz, T. (1993) «From hegemony to subordination: midwifery in early modern Spain», The art of midwifery. Early modern midwives in Europe, London / New York, Routledge, pp. 95-114.

SCRIPTA, Revista internacional de literatura i cultura medieval i moderna, núm. 16 / desembre 2020 / pp. 320-342 ISSN: 2340-4841 · doi:10.7203/SCRIPTA.16.19233 
Carmel Ferragud \& Guillem Roca. El cos de la dona maltractada, sota l'escrutini mèdic: els casos de València i Lleida en la baixa edat mitjana

Pastor, R. (2005) «Mujeres populares. Realidades y representaciones», dins Morant, I. (dir.), Historia de las mujeres en España y la América Latina. vol. I. De la prehistoria a la edad media, Madrid, Cátedra, pp. 456-457.

Riera i Sans, J. (1987) El cavaller i l'alcavota, Barcelona, Club Editor.

Roca, G. (2017) Salubritat i salut pública a la Lleida baix medieval. La gestió dels espais públics, la pobresa i els hospitals, tesi doctoral dirigida per J. J. Busqueta, Lleida, Universitat de Lleida.

Rodríguez, V. (1997) Historia de la violación: su regulación jurídica hasta fines de la Edad Media, Madrid, Consejería de Educación y cultura de la comunidad de Madrid.

Roig, J. (2014) Espill, ed. Antònia Carré, Barcelona, Barcino.

Romeu, S. (1982) «La mujer en el derecho penal valenciano», Estudios dedicados a Juan Peset Aleixandre, València, Universitat de València, III, pp. 459-473.

Rubio Vela, A. (1979) «Las epidemias de peste en la ciudad de Valencia durante el siglo XV: nuevas aportaciones», Estudis Castellonencs, 6, pp. 1179-1222.

Sabaté, F. (1994) «Femmes et violence dans la Catalogne du XIVe siècle», Annales du Midi, 106/207, pp. 277-316.

—_. (2007) El somenten a la Catalunya medieval, Barcelona, Rafael Dalmau Editor.

Serna, J. (1990) «Los límites de la reclusión carcelaria en la Valencia bajomedieval», Revista d'bistoria medieval, 1, pp. 39-57.

Viera, D. J. / Piqué, J. (1987) La dona en Francesc Eiximenis, Barcelona, Curial.

Viera, D. J. / Piqué J. / Camaño, R. (2010) «Malaltia i salut en l'obra de Francesc Eiximenis», Caplletra, 48, pp. 179-209.

Vinyoles, T. (1997) «Queixes dels pobres presos de la presó de Barcelona (1445)», Acta historica et archaeologica mediaevalia, 18 , pp. 67-88

(2011) «De medicina, de magia y de amor: saberes y prácticas femeninas en la documentación catalana bajomedieval», Clioe Crimen, Revista del Centro de Historia del Crimen de Durango, 8, pp. 225-246.

Vinyoles, T. / Comas, M. (2015) «Lo Libre de les dones», dins Riera, A. (ed.), Francesc Eiximenis (C.1330-1409): el context i l'obra d'un gran pensador català medieval, Barcelona, Institut d'Estudis Catalans, pp. 267-288. 